\title{
Issue 44
}

Written by Administrator

Wednesday, 20 March 2019 14:56 - Last Updated Tuesday, 04 June 2019 15:49

Download

https://doi.org/10.17721/2308-135 $\underline{\text { X }} \underline{\text { 2019.44.3-12 }}$

UDC 911.3

Pestushko Valery Yurijovy ch, Ph.D. (Geography), Associate Professor, National Aviation University, Kiev, Ukraine, e-mail:

pestushk054@gmail.com

AVIA PASSENGER TRANSPORTATION AND TOURISM: INTERACTION FEATURES

Purpose: a study of the current state and prospects of avia passenger transportation in international tourism as prerequisites for strategic planning of the tourism business.

Methodology: collection, analysis, systematization and synthesis of the latest statistical data of the World Tourism Organization and the International Civil Aviation Organization on avia transportation in tourism.

Results: data on the dynamics of avia transportation in tourism in the current century were 


\section{Issue 44}

Written by Administrator

Wednesday, 20 March 2019 14:56 - Last Updated Tuesday, 04 June 2019 15:49

obtained, the socio-economic role of avia transportation in tourism was clarified, and the structure of avia passenger transportation by tourist regions was determined.

Scientific novelty: the current trends and prospects for the further use of avia transportation means in the tourist services market are identified.

Practical significance: the results of the study can be used both in the educational process in the development of experts in tourism, and in the tactical and strategic planning of the tourism business.

Keywords: avia passenger transportation, tourism.

References:

1.Aviation benefits beyond borders-2018. [Електронний ресурс]. - Режим доступу: https://av iationbenefits.org/

2.ICAO. Facts \& Figures. [Електронний ресурс]. - Режим доступу: https://www.icao.int/sust ainability/Pages/FactsFigures-Data.aspx

3.MasterCard 2018 . GlobalDestinationCitiesIndex 2015.[Електронний ресурс]. - Режим доступу: Tourism Towards 2030. Global Overview

4.Uniting Travel. Travel \& Tourism - a force for goodin the world. [Електронний ресурс]. Режим доступу: https://www.unitingtravel.org/

5.UNWTO/ICAO High-level forum on tourism and air transport for development. Monday, 14 September 2015, Medellín, Colombia.[Електронний ресурc]. - Режим доступу: http://cf.cdn. 


\section{Issue 44}

Written by Administrator

Wednesday, 20 March 2019 14:56 - Last Updated Tuesday, 04 June 2019 15:49

unwto.org/sites/all/files/pdf/unwto_icao-high-levelforumrev2_en.pdf

6.World Tourism Organization (UNWTO). Visa Openness Report 2015. January 2016. [Електронний ресурс]. - Режим доступу: dn.unwto.org/sites/all/files/docpdf/2015visaopennessreportonline.pdf

http://cf.c

7.World Tourism Organization UNWTO [Електронний ресурс]. - Режим доступу: http://www 2.unwto.org/

8. Balabanov V., Tkachuk L. Analysis of the interaction processes in the aviation-tourism system // Bulletin of the Institute of International Relations NAU. Series: Economics, Law, Political Science, Tourism. - M.: Publishing house "NAU-print", 2010. - Vol. 1. - p. 171-179.

9. Balabanov V., Tkachuk $L$. The development of aviation transport as a factor in improving Ukraine's competitiveness in the global market of tourist services // Geography and tourism: Sciences. Sat - M.: Alterpress, 2011. - Vol. 14. - p. 159-166.

10.Borisyuk, A.A., I.V. Zarya. Competitive base of air transport in the conditions of development of travel companies // Geography and tourism: Sat. sciences. works. - M.: Alterpress, 2011.Vol. 22. - p. 18-27.

11.Borisyuk A.A. Air transport system as a factor in the development of international tourism in Ukraine // Tourism business: global trends and national priorities: materials $V$ Intern. scientific practice. conf. - M.: KhNU them. V.N. Karazin, 2011. - pp. 28-34.

12. Dudnik I.M., Borisyuk A.A. The question of the territorial organization of the air transport infrastructure as a factor in the development of tourism in Ukraine // Tourism and hospitality in Ukraine: state, problems, trends, development prospects and international scientific practice. Conf., November 1-2, 2012 - Cherkasy: Brama-Ukraine, 2012. - p. 277-283. 
13. Pestushko V.Yu. Trends in the development of world tourist traffic // Interaction between transport and tourism: trends, problems and prospects. Sat Science.pr.ts.-K .: Print Center, 2012.-C.34-39.

14.Pristayko A.P., Pinsk I.P. Influence of the tourism industry on the functioning of airlines // Economy. Finance. Law: information and analytical scientometric journal. - 2017. - №4. - pp. 31-34.

15. Tkachuk $L$. Transformations in the field of air transportation: challenges for tourism // Geography and tourism: Sat. sciences. works. - M.: Alterpress 2013. -Vip.21. -WITH. 79-84.

16. Uvarova G. Sh. Ukrainian aviation in the international market of tourist services: problems and development prospects // Materials of the international scientific-practical conference State policy of development of civil aviation of the XXI century: economic patriotism and strategic opportunities 